\title{
Common epitopes in LPS of different Enterobacteriaceae are associated with an immune response against Escherichia coli O157 in bovine serum samples
}

\author{
Armando Navarro, ${ }^{1}$ Carlos Eslava, ${ }_{1}^{1}$ Guadalupe García de la Torre, ${ }^{1}$ \\ Luis Antonio León, ${ }^{1}$ Delia Licona, ${ }^{1}$ Lemuel León, ${ }^{2}$ Luis Alberto Zarco ${ }^{3}$ \\ and Alejandro Cravioto ${ }^{1}$ \\ ${ }^{1}$ Departamento de Salud Pública, Facultad de Medicina, Universidad Nacional Autónoma de \\ México, Ciudad Universitaria, D. F. 04510, Mexico \\ ${ }^{2}$ Universidad Autónoma del Estado de México, Mexico \\ ${ }^{3}$ Facultad de Medicina Veterinaria y Zootecnia, Universidad Nacional Autónoma de México, Ciudad \\ Universitaria, D. F., Mexico
}

Correspondence

Armando Navarro

arnava@servidor.unam.mx

Received 1 February 2007

Accepted 5 July 2007

\begin{abstract}
Epidemiological studies in both humans and animals conducted in Mexico have shown that the isolation frequency of Escherichia coli $\mathrm{O} 157: \mathrm{H} 7$ is low. In a previous study, lgG antibodies against $E$. coli O157, O7 and O116 LPS were found in serum samples from children and adults with no previous history of $E$. coli $\mathrm{O} 157: \mathrm{H} 7$ infection. The present study was designed to determine whether a similar immune response against $E$. coli $\mathrm{O} 157: \mathrm{H} 7$ and other antigenically related bacteria was present in bovine serum samples. A total of 310 serum samples from different herds in Mexico was analysed by microagglutination assays against different enterobacterial antigens, including E. coli O157. Microagglutination assays were positive against E. coli O7 (55\%), O116 (76\%) and O157 (36\%), Escherichia hermannii (15\%), Salmonella enterica serotype Urbana (14\%) and Salmonella enterica subsp. arizonae (40\%). These results were confirmed using a specific ELISA with purified LPS. A positive reaction was observed against the LPS of E. coli O7 (29\%), O116 (12\%) and O157 (22\%), E. hermannii (4\%), Salmonella Urbana (13\%) and S. enterica subsp. arizonae (12\%). Serum absorption studies of positive serum samples indicated the existence of at least three common epitopes shared by the LPS of E. coli O7, O116 and O157, and two others between E. coli O157 and Salmonella Urbana and S. enterica subsp. arizonae. A bactericidal assay against E. coli $\mathrm{O} 157: \mathrm{H} 7 \mathrm{Hsing} 31$ bovine serum samples was performed, and $22(71 \%)$ of these serum samples gave positive results. The data demonstrated that bovine serum showed a response against different enterobacteria, including $E$. coli $\mathrm{O} 157$, and that this response could be due to the presence of shared epitopes in the LPS of these organisms.
\end{abstract}

\section{INTRODUCTION}

Escherichia coli $\mathrm{O} 157: \mathrm{H} 7$ infection and the consequent associated diseases constitute an important health problem for children and the elderly, mainly in developed countries (Bitzan et al., 1993; Gillespie et al., 2005; Griffin \& Tauxe, 1991; Rangel et al., 2005). Cattle and sheep are natural reservoirs, and are also important transmission vectors for these bacteria (Chapman et al., 1997; Hancock et al., 1997). Isolation rates have been widely reported (Naylor et al., 2005), with levels of $1.8 \%$ in Japan (Miyao et al., 1998),

Abbreviations: UNAM, Universidad Nacional Autónoma de México; VTEC, Vero cytotoxin-producing Escherichia coli.
$1.9 \%$ in Australia (Cobbold \& Desmarchelier, 2000) and from 0 to $7.4 \%$ in the USA (Faith et al., 1996). In Mexico, serotyping data of approximately $16000 \mathrm{E}$. coli isolates collected over the past 20 years have shown an isolation frequency of $1 \%$ for E. coli O157 strains (Navarro et al., 2003). In another study in Mexico, Callaway et al. (2004) showed an isolation frequency of $1.25 \%$ for E. coli $\mathrm{O} 157$ in cattle and $2.1 \%$ in swine. Studies conducted in countries with defined outbreaks of haemolytic uraemic syndrome or haemorrhagic colitis associated with the presence of $E$. coli O157:H7 strains have shown that patients infected with these strains exhibit increased levels of $\operatorname{IgA}, \operatorname{IgG}$ and $\operatorname{IgM}$ against the O157 LPS (Chart \& Rowe, 1992; Greatorex \& 
Thorne, 1994). In a previous study, $20 \%$ of serum samples from 605 Mexican children and adults showed detectable levels of IgG against E. coli O157 LPS (Navarro et al., 2003). The LPS is located in the outer membrane of Gramnegative bacteria, and usually consists of three distinct regions: lipid $\mathrm{A}$, core oligosaccharide and the $\mathrm{O}$ antigen (Caroff \& Karibian, 2003). Analysis of the LPS O antigens produced by Salmonella group N (Bundle et al., 1986), Escherichia hermannii, Brucella abortus (Perry \& Bundle, 1990), Vibrio cholerae O1 (Kenne et al., 1982), Yersinia enterocolitica and E. coli O157 (Perry et al., 1986) has revealed that a common structural epitope consisting of $N$ acetyl derivatives of 4 -amino-4,6-dideoxy- $\alpha$-D-mannopyranosyl residues is present in each respective LPS O antigen and that this factor is responsible for the observed serological cross-reactions. Considering our previous findings in human serum samples (Navarro et al., 2003), the current study was designed to determine the immune response of bovine serum samples against $E$. coli $\mathrm{O} 157$ : $\mathrm{H} 7$ and other antigenically related bacteria.

\section{METHODS}

Bacterial strains. The bacterial strains used in this study are listed in Table 1. Prior to use, they were analysed for purity and then conserved in Dorset's medium until required.

Bovine serum samples. A total of 310 bovine serum samples obtained from two adult cattle herds in Mexico were included in the study. Of these, 100 samples were obtained from farms belonging to the School of Veterinary Medicine, National Autonomous University of Mexico (UNAM) and 210 samples from cattle raised in the State of Mexico, adjoining Mexico City. UNAM cattle were raised for veterinary purposes, whilst cattle in the State of Mexico was raised for milk and meat production.

Rabbit serum samples. Anti-LPS sera against bacterial antigens were raised in rabbits using the procedures described by Ewing (1986).

Table 1. Bacterial strains used in this study

\begin{tabular}{|lll|}
\hline Strain no. & \multicolumn{1}{c|}{ Identification } & \multicolumn{1}{c|}{ Serotype } \\
\hline Bi7509-41* $^{*}$ & E. coli & $\mathrm{O} 7: \mathrm{NM}$ \\
$28 \mathrm{w}^{*}$ & E. coli & $\mathrm{O} 116: \mathrm{H} 10$ \\
$\mathrm{~A}^{*}$ & E. coli & $\mathrm{O} 157: \mathrm{H} 19$ \\
$\mathrm{EDL} \mathrm{933} \mathrm{(ATCC}$ & E. coli & $\mathrm{O} 157: \mathrm{H7}$ \\
$700927)$ & & \\
FMU 110538 $\dagger$ & E. hermannii & \\
FMU 108459 $\ddagger$ & S. enterica serotype Urbana \\
FMU 108308 $\dagger$ & S. enterica subsp. arizonae & \\
\hline
\end{tabular}

${ }^{*}$ Strains provided by the Division of Enteric Pathogens, Health Protection Agency, London, UK.

$\dagger$ Strains isolated and characterized in the Public Health Laboratory, Medicine School, UNAM, and used for the different assays.

$\ddagger$ Strain provided by the Laboratory of Microbiology, National Institute of Reference and Epidemiological Diagnosis (INDRE), Mexico.
Microagglutination assay. The serum response to bacterial surface antigens was determined according to Ørskov \& Ørskov (1984). Strain purity was verified on both blood and MacConkey agar following overnight incubation at $37{ }^{\circ} \mathrm{C}$. Smooth colonies were then taken from the blood agar culture, plated onto tryptic soy agar (TSA; Difco) and incubated overnight at $37{ }^{\circ} \mathrm{C}$. Developing colonies from each plate were harvested and diluted in $0.15 \mathrm{M}$ saline solution. The suspension was then boiled at $100{ }^{\circ} \mathrm{C}$ for $1 \mathrm{~h}$ and adjusted with $0.6 \%$ $(\mathrm{v} / \mathrm{v})$ formaldehyde/saline solution to a McFarland no. 3 standard to give a concentration of $3.0 \times 10^{8}$ bacteria $\mathrm{ml}^{-1}$.

For the agglutination assays, $50 \mu \mathrm{l}$ of serial dilutions of the bovine serum samples (from $1: 10$ to $1: 1280$ ) were dispensed into 96-well microtitre plates (Nunc) containing $50 \mu$ of the adjusted bacterial suspension, and incubated for between 18 and $24 \mathrm{~h}$ at $50{ }^{\circ} \mathrm{C}$, as described by Ewing (1986). Serum samples capable of agglutinating the bacterial suspensions at a dilution of $1: 160$ or more were considered positive. Differences in the titres between serum samples were compared using a $\chi^{2}$ test.

LPS purification. Bacterial LPS was obtained using the phenol/water method described by Westphal \& Jann (1965). The purity of LPS samples was enhanced by treatment with DNase, RNase and proteinase K (Sigma).

ELISA. The presence of IgG antibodies against the bacterial LPS (Table 1) in the bovine serum samples was determined using an ELISA test as described by Chart et al. (1989). Briefly, 96-well flatbottomed plates (Immulon) were coated with $1 \mu \mathrm{g}$ each LPS in $100 \mu \mathrm{l}$ coating buffer (1.59 $\mathrm{g} \mathrm{NaCO}_{3} \mathrm{l}^{-1}, 2.93 \mathrm{~g} \mathrm{NaCHO}_{3} \mathrm{l}^{-1}$, pH 9.6). After washing with PBS containing $0.5 \%(\mathrm{v} / \mathrm{v})$ Tween 20 (PBS-Tween), non-specific binding sites were blocked by the addition of $200 \mu \mathrm{l} 1 \%$ $(\mathrm{w} / \mathrm{v})$ BSA in PBS-Tween $\left(30 \mathrm{~min}, 37^{\circ} \mathrm{C}\right)$. Aliquots of $100 \mu \mathrm{l}$ of the diluted bovine serum samples $(1: 1000)$ were added to plates and incubated at $37^{\circ} \mathrm{C}$ for a further $2 \mathrm{~h}$. The plates were then washed three times with PBS-Tween, and $100 \mu \mathrm{l}$ goat anti-bovine IgG (diluted 1:1000) labelled with alkaline phosphatase (Zymed Laboratories) was added to each well. Plates were incubated at $37{ }^{\circ} \mathrm{C}$ for $2 \mathrm{~h}$ and washed three times with PBS-Tween. To visualize the reaction, $200 \mu \mathrm{l} p$-nitrophenyl phosphate $\left(1 \mathrm{mg} \mathrm{ml}^{-1}\right.$; Sigma $)$ in diethanolamine buffer ( $\mathrm{pH}$ 9.8; Sigma) was added. The plates were incubated at room temperature for $30 \mathrm{~min}$ and the reaction was stopped by adding $25 \mu \mathrm{l} 3 \mathrm{M} \mathrm{NaOH}$. $A_{405}$ was measured in an ELISA microplate reader (MR 580; Dynatech Instruments). The assays were processed in duplicate and the mean value obtained from the two tests was used for the statistical analysis. A cut-off point of 0.7 at a $1: 1000$ serum dilution was considered a positive ELISA result, as described previously (Navarro et al., 2003).

Antigenic relationships. To determine the existence of common epitopes among E. coli O157, O7 and O116, and between E. coli O157 and Salmonella enterica serotype Urbana and Salmonella enterica subsp. arizonae, seven bovine serum samples were selected for further study. Five of these showed a response to E. coli (O7, O116 and O157), and two responded to the O157 and Salmonella Urbana boiled antigens. Serum samples from rabbits immunized individually against E. coli O157, Salmonella Urbana or S. enterica subsp. arizonae were also analysed. The serum absorption studies were conducted according to the method of Ewing (1986). In brief, bacteria were grown overnight on blood agar plates at $37{ }^{\circ} \mathrm{C}$ and smooth colonies were selected and inoculated onto TSA plates. The cultures were incubated overnight at $37{ }^{\circ} \mathrm{C}$ and the bacteria were harvested in $10 \mathrm{ml}$ $0.15 \mathrm{M}$ saline solution, boiled at $100{ }^{\circ} \mathrm{C}$ for $1 \mathrm{~h}$ and adjusted to a McFarland no. 10 standard to give a concentration of $9 \times 10^{8}$ bacteria $\mathrm{ml}^{-1}$. The bacterial suspension was centrifuged $(6000 \mathrm{~g}, 10 \mathrm{~min}$, $4{ }^{\circ} \mathrm{C}$ ), and the pellets were mixed with $0.5 \mathrm{ml}$ of each selected serum sample and then incubated for $2 \mathrm{~h}$ at $50{ }^{\circ} \mathrm{C}$. The samples were 
centrifuged $\left(6000 \mathrm{~g}, 10 \mathrm{~min}, 4{ }^{\circ} \mathrm{C}\right)$ to separate the supernatant, and then tested for agglutination against bacterial suspensions of $E$. coli O157, O7 and O116, Salmonella Urbana and S. enterica subsp. arizonae as described previously to determine whether the crossreactions present in the original serum sample had been eliminated after each procedure.

Serum bactericidal activity. The serum bactericidal activity against a prototype E. coli O157:H7 strain (EDL 933, ATCC 700927) was determined in 31 of the 310 serum samples using a method described by Qadri et al. (1995). Samples were selected according to their ELISA results: serum samples that had a response against all three E. coli LPS antigens (O7, O116 and O157), serum samples that had a response against two of these antigens together (E. coli O7 and $\mathrm{O} 157$ or $\mathrm{O} 116$ and O157), serum samples that had a response against a single antigen (E. coli $\mathrm{O} 7$ or $\mathrm{O} 116$ or $\mathrm{O} 157$ ) or serum samples without a response to the three LPS antigens. In brief, E. coli O157: H7 was inoculated onto brain heart infusion (BHI) agar plates (Difco) and incubated at $37{ }^{\circ} \mathrm{C}$ for $18 \mathrm{~h}$. Samples of the resulting cultures were plated onto BHI plates and incubated at $37{ }^{\circ} \mathrm{C}$ for $4 \mathrm{~h}$. Suspensions from these cultures containing $1.5 \times 10^{8}$ bacteria $\mathrm{ml}^{-1}$ were prepared in $0.15 \mathrm{M}$ saline solution. Bactericidal assays were performed by mixing $1 \mathrm{ml}$ bacterial suspension with $2 \mathrm{ml}$ guinea pig complement (Sigma) and $17 \mathrm{ml}$ cold saline solution. Aliquots of $25 \mu \mathrm{l}$ were mixed with $25 \mu \mathrm{l}$ of positive (against O157 LPS) or negative bovine serum samples initially diluted $1: 2$, and then diluted twofold in 96-well microplates and incubated at $37{ }^{\circ} \mathrm{C}$ for $1 \mathrm{~h}$. One of the microplate wells containing all assay components except serum was used as a control for bacterial growth. BHI broth $(150 \mu \mathrm{l})$ was added to the wells and the mixture was incubated at $37^{\circ} \mathrm{C}$ for a further $3 \mathrm{~h}$, followed by $18 \mathrm{~h}$ incubation at $4{ }^{\circ} \mathrm{C}$. The bactericidal effect of the serum samples was determined by determining the number of c.f.u. The prevalence of ELISA-positive and -negative serum samples was determined by comparing the mean numbers of c.f.u. in three separate assays. For statistical analysis, the mean c.f.u. values of the three independent assays were compared by one-tailed analysis of variance with a significance level of $P<0.05$.

\section{RESULTS AND DISCUSSION}

\section{Bovine serum response to LPS antigens}

Serum samples obtained from 310 cows from two different herds were analysed by agglutination assays and ELISA. Microagglutination assays showed that $169(55 \%)$ of the samples were positive for E. coli O7, 237 (76\%) for E. coli
O116 and 112 (36\%) for E. coli O157 (Table 2). In addition, 47 samples (15\%) reacted with E. hermannii, 43 (14\%) with Salmonella Urbana and $125(40 \%)$ with S. enterica subsp. arizonae. Analysis by ELISA showed that $29 \%$ of the serum samples reacted with E. coli O7 LPS, $12 \%$ with O116 LPS and $22 \%$ with O157 LPS (Table 3). The serum response against other bacteria showed that $4 \%$ of samples reacted with E. hermannii LPS, $13 \%$ with Salmonella Urbana LPS and $12 \%$ with S. enterica subsp. arizonae LPS (Table 3). Location or the conditions under which the animals were kept appeared to be important determinants for the type of immune response against the different antigens tested. Cattle kept in open farms in the State of Mexico showed a higher response to E. coli O157 than cows that had been bred at the UNAM farms (45 vs $17 \%$ in the agglutination assay and 27 vs $12 \%$ by ELISA, $P<0.05)$. Other significant differences between the UNAM and State of Mexico herds was the serum response to $E$. hermannii ( 23 vs $11 \%, P<0.05$ ), Salmonella Urbana ( 22 vs $10 \%, P<0.05)$ and $S$. enterica subsp. arizonae ( $55 \%$ vs $33 \%, P<0.05)$. Furthermore, the ELISA results showed that the response to Salmonella Urbana LPS was significantly higher in serum samples from animals kept in farms in the State of Mexico $(P<0.05)$. The differences in the immune response were similar regardless of the evaluation method employed. Differences observed in the serum responses between the two farms could therefore be due to factors other than the sensitivity of the test employed or the characteristics of the antigens used, and could include climatic and dietary conditions (Caprioli et al., 2005), differences in the cows themselves or differences in the conditions of the feedlot pen (Smith et al., 2001). These latter factors were not analysed as part of the current study.

The observed immune response against E. coli O157 in Mexican cattle serum samples was lower (22\%) than that reported for beef calves at weaning raised in the USA, in which $60-100 \%$ of serum samples were positive (Laegreid et al., 1999). It is important to note that, in this last study, up to $20 \%$ of the animals were found to be shedding E. coli O157:H7 in their faeces. A recent study analysing beef

Table 2. Agglutination assays against different enterobacterial antigens

Results of agglutination assays using dilutions of between $1: 160$ and $1: 1280$, showing the number of positive samples. Percentages are shown in parentheses.

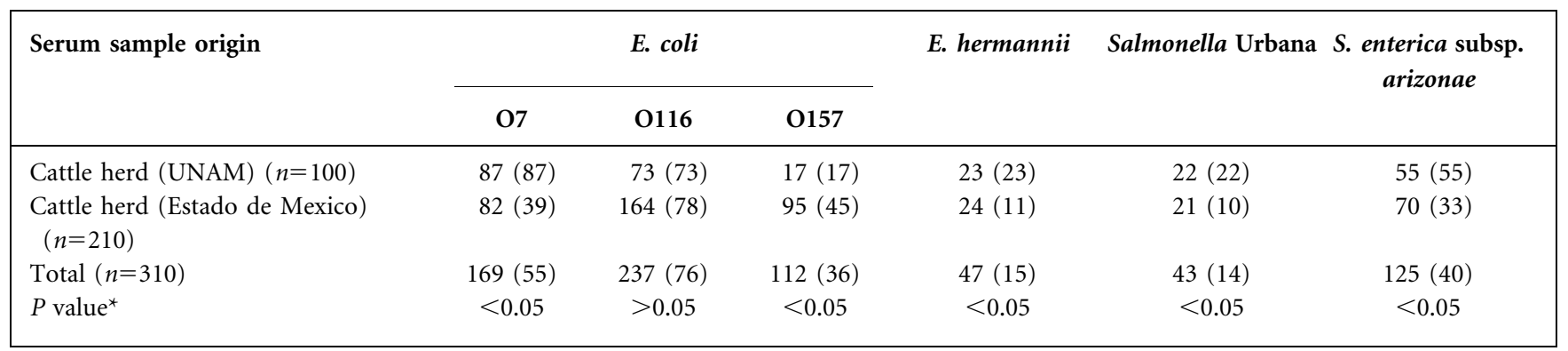

${ }^{\star}$ Statistical difference between the two herds using a $\chi^{2}$ test. 
Table 3. ELISA against different enterobacterial lipopolysaccharides

The ELISA used a cut-off point of $>0.7$ at $A_{405}$ at a serum dilution of $1: 1000$. Results are shown as the number of positive samples, with the percentage in parentheses.

\begin{tabular}{|c|c|c|c|c|c|c|}
\hline \multirow[t]{2}{*}{ Serum sample origin } & \multicolumn{3}{|c|}{ E. coli } & \multirow[t]{2}{*}{ E. hermannii } & \multirow[t]{2}{*}{ Salmonella Urbana } & \multirow{2}{*}{$\begin{array}{c}\text { S. enterica subsp. } \\
\text { arizonae }\end{array}$} \\
\hline & 07 & 0116 & 0157 & & & \\
\hline Cattle herd (UNAM) $(n=100)$ & $28(28)$ & $9(9)$ & $12(12)$ & $6(6)$ & $7(7)$ & $12(12)$ \\
\hline Cattle herd (Estado de Mexico) $(n=210)$ & $62(30)$ & $29(14)$ & $57(27)$ & $5(2)$ & $32(15)$ & $26(12)$ \\
\hline Total $(n=310)$ & $90(29)$ & $38(12)$ & $69(22)$ & $11(4)$ & $39(13)$ & $38(12)$ \\
\hline$P$ value & $>0.05$ & $>0.05$ & $<0.05$ & $>0.05$ & $<0.05$ & $>0.05$ \\
\hline
\end{tabular}

${ }^{\star}$ Statistical difference between the two herds using a $\chi^{2}$ test.

carcasses in Mexico (Varela-Hernández et al., 2007) showed frequencies of $5 \%$ for non-motile E. coli $\mathrm{O} 157$ and $2.7 \%$ for E. coli O157: H7, somewhat lower than those observed by Laegreid et al. (1999). In the current study, the results also demonstrated that serum samples from the two herds reacted against LPS antigens of Salmonella, different E. coli serogroups and E. hermannii, bacteria that have been shown to cross-react with the O157 LPS (Ewing, 1986; Perry et al., 1986; Rice et al., 1992). E. coli O157 LPS contains a tetrasaccharide repeat unit of $N$-acetyl derivatives of 4-amino-4,6-dideoxy- $\alpha$-D-mannopyranosyl residues, which are also present in Salmonella Urbana LPS (Samuel et al., 2004) and in other Enterobacteriaceae (Nishiuchi et al., 2000; Rice et al., 1992). This finding could help to explain our results. However, other surface structures including outer-membrane proteins, LPS-associated proteins and the type of core present in the LPS could be also involved in this bovine immune response. Currie et al. (2001) observed high levels of both systemic and local IgA against O157 LPS in patients recovering from an E. coli O157: H7 infection. This IgA response appeared to have been caused, at least in part, by the R3 core of the O157 LPS. Different studies (Amor et al., 2000; Chart et al., 2002; Currie \& Poxton, 1999) have shown that E. coli $\mathrm{O} 157$ and some other Vero cytotoxin-producing E. coli (VTEC) belonging to serogroups O26, O55, O86, O111 and O128 carry a similar R3 LPS core. Gibbs et al. (2004) reported a statistically significant difference in the level of R3 core LPS in bovine commensal E. coli strains when compared with human strains. This suggests that there is a correlation between the elevated anti-R3 core serum response and contact with a greater number of species related to VTEC and enteropathogenic E. coli (EPEC) within the commensal bacterial populations of cattle. Serotyping studies of E. coli strains isolated in Mexico from different sources (Cravioto et al., 1990) have also shown the existence of VTEC and EPEC strains in humans and animals. The long exposure of Mexican cattle to all of these environmental antigens could be related to the development of an immune response to different antigens associated with E. coli O157.

\section{Antigenic relationships}

Five of the bovine serum samples with the highest titres obtained in the ELISA assays against E. coli O7, O116 and O157 LPS were selected for absorption assays. These samples, plus two others chosen at random, were used to determine whether the existence of common epitopes was responsible for the cross-reacting immune results. Reactions against E. coli O7, O116 and O157 LPS antigens in these samples were completely abolished when the sera were absorbed with E. coli O7, O116 and O157 (Table 4). Similar negative results against the three antigens were seen when the sera were absorbed with E. coli O7 and $\mathrm{O} 116$ only, or with E. coli $\mathrm{O} 7$ and O157. Interestingly, when the same serum samples were absorbed with E. coli O116 and O157, the agglutination was negative against both antigens but not against the E. coli O7 antigen (Table 4). These results suggested the existence of at least three shared epitopes among E. coli O7, O116 and O157 strains.

Table 4. Detection of common epitopes in E. coli strains of different serogroups by absorption assays of bovine serum samples

\begin{tabular}{|lccc|}
\hline $\begin{array}{l}\text { Bovine serum sample } \\
(\boldsymbol{n}=\mathbf{5})\end{array}$ & \multicolumn{3}{c|}{$\boldsymbol{E}$ coli antigen agglutination titre } \\
\cline { 2 - 4 } & $\mathbf{O 7}$ & $\mathbf{O 1 1 6}$ & $\mathbf{O 1 5 7}$ \\
\hline $\begin{array}{l}\text { Non-absorbed sera } \\
\text { Sera absorbed with: } \dagger\end{array}$ & $1: 320$ & $1: 160$ & $1: 160$ \\
O7+ O116+O157 & 0 & 0 & 0 \\
O7 & 0 & $1: 40$ & $1: 20$ \\
O116 & $1: 80$ & 0 & 0 \\
O157 & $1: 40$ & $1: 40$ & 0 \\
O7+O116 & 0 & 0 & 0 \\
O7+O157 & 0 & 0 & 0 \\
O116+O157 & $1: 40$ & 0 & 0 \\
\hline
\end{tabular}

*Analysis of bovine serum samples that showed similar reactions to O7, O116 and O157 LPS.

$\dagger$ Serum was absorbed with boiled antigen for $1 \mathrm{~h}$. 
Table 5. Common epitopes between E. coli 0157 and Salmonella Urbana identified in bovine serum samples by absorption assays

\begin{tabular}{|llcc|}
\hline $\begin{array}{l}\text { Bovine } \\
\text { serum } \\
\text { sample }\end{array}$ & \multicolumn{1}{c}{ Absorbed with:* } & \multicolumn{2}{c|}{ Agglutination titre } \\
& & E. coli O157 & $\begin{array}{c}\text { Salmonella } \\
\text { Urbana }\end{array}$ \\
\cline { 3 - 4 } & & & $1: 320$ \\
\hline B47 & Non-absorbed & $1: 1280$ & $1: 160$ \\
B60 & Non-absorbed & $1: 320$ & 0 \\
B47 & O157 & 0 & 0 \\
B60 & O157 & 0 & 0 \\
B47 & Salmonella Urbana & $1: 160$ & 0 \\
B60 & Salmonella Urbana & $1: 160$ & 0 \\
B47 & O157+ Salmonella Urbana & 0 & 0 \\
B60 & O157+ Salmonella Urbana & 0 & \\
& & & \\
\hline
\end{tabular}

${ }^{\star}$ Serum was absorbed with boiled antigen for $1 \mathrm{~h}$.

Similar assays with bovine serum samples that reacted against both E. coli $\mathrm{O} 157$ and Salmonella Urbana showed that absorption with E. coli $\mathrm{O} 157$ induced a negative agglutination reaction against both antigens (Table 5). Absorption with Salmonella Urbana caused a negative response against the homologous antigen (Salmonella Urbana) and only a reduction in titre against $E$. coli O157. These results also suggested the existence of a shared epitope between the E. coli O157 and Salmonella Urbana antigens.

Three rabbit serum samples raised individually against $E$. coli O157, Salmonella Urbana and S. enterica subsp. arizonae were analysed by absorption assays to confirm the previous observations. E. coli O157 antisera showed titres of $1: 3200$ to the homologous antigen, and titres of 1:1600 to Salmonella Urbana and S. enterica subsp. arizonae (Table 6). The absorption of E. coli O157 serum with Salmonella Urbana antigen produced a negative response against the homologous and heterologous antigens. However, when the absorption of this serum was carried out with $S$. enterica subsp. arizonae, there was only a reduction in the titres against E. coli $\mathrm{O} 157$ and Salmonella Urbana antigens, whilst the response against $S$. enterica subsp. arizonae was completely suppressed by the procedure. The rabbit serum prepared against Salmonella Urbana showed the same titre $(1: 1600)$ against E. coli O157 and against the homologous antigens. The absorption of this serum with E. coli $\mathrm{O} 157$ induced a negative response against both the E. coli $\mathrm{O} 157$ and S. enterica subsp. arizonae antigens, in addition to a reduction in the titre against Salmonella Urbana.

Rabbit antiserum raised against $S$. enterica subsp. arizonae showed titres of $1: 1600$ against the homologous antigen, and titres of $1: 800$ and $1: 200$ against E. coli O157 and Salmonella Urbana, respectively (Table 6). The absorption of this rabbit serum with E. coli $\mathrm{O} 157$ antigens led to a negative response against E. coli $\mathrm{O} 157$ and Salmonella Urbana antigens, and to a reduction in titre against the homologous antigen (S. enterica subsp. arizonae). Analysis of these absorption results suggested the existence of at least one shared epitope between E. coli O157 and Salmonella Urbana, and another between E. coli O157 and S. enterica subsp. arizonae. Although common epitopes between E. coli O157 and Salmonella Urbana have been reported (Samuel et al., 2004), the existence of common epitopes between E. coli $\mathrm{O} 157$ and S. enterica subsp. arizonae has not. These observations suggested that the serum response against E. coli $\mathrm{O} 157$ observed in this study could be associated with a heterologous immune response against other more common bacteria.

The existence of core epitopes shared by different E. coli, including O157:H7 (Chart et al., 2002; Currie \& Poxton, 1999), and Salmonella and Shigella spp. (Gibb et al., 1992), suggests the possibility of the production of a crossprotective immune response. Currie et al. (2001) observed that a group of workers constantly exposed to different organisms in a slaughterhouse showed elevated levels of IgM to the R3 LPS core. These findings suggest that a high frequency of exposure to organisms with shared epitopes could be associated with the presence of a protective immune response.

\section{Serum bactericidal activity}

The bactericidal response against E. coli $\mathrm{O} 157$ was positive in 22 of the 31 selected bovine serum samples. The bactericidal titres ranging from serum dilutions of $1: 2$ to $1: 64$ coincided with c.f.u. counts of between $1.16 \times 10^{7}$ and $17.20 \times 10^{7}$ c.f.u. $\mathrm{ml}^{-1}$, compared with $28.83 \times 10^{8}$ c.f.u. $\mathrm{ml}^{-1}$ found in the negative control; this difference was statistically significant $(P<0.05)$ (Table 7$)$. Analysis of the reactivity of the 22 serum samples against the different LPSs used in this study indicated that six were positive against O157 LPS only, three reacted with both O157 and O7 LPS, two reacted with O7 LPS, two with O7 and O116 LPS, and nine reacted with all three LPS antigens (O7, O116 and O157). The nine serum samples without bactericidal activity against $\mathrm{O} 157: \mathrm{H} 7$ showed a response against O157 LPS only by ELISA, two reacted with both O7 and O157 LPS antigens, one reacted with O7 LPS only, one with both O116 and O157 LPS antigens, and three showed no response to any of the E. coli LPSs studied.

The neutralizing capacity of serum antibodies is important for the host to eliminate micro-organisms from mucosal surfaces. Studies carried out using O157-specific polysaccharide-protein conjugates in vaccinated adults (Konadu et al., 1998), children (Ahmed et al., 2006) and mice have shown that serum IgG LPS antibodies with high bactericidal activity titres have a protective immune response (Konadu et al., 1994). Similarly, cattle colonized with enteric organisms that share common repeating units in 
Table 6. Common epitopes between E. coli $\mathrm{O} 157$ and Salmonella Urbana, and E. coli O157 and S. enterica subsp. arizonae, identified in rabbit serum by absorption assays

\begin{tabular}{|c|c|c|c|c|}
\hline \multirow[t]{2}{*}{ Serum sample } & \multirow[t]{2}{*}{ Absorbed with: ${ }^{*}$} & \multicolumn{3}{|c|}{ Agglutination titre } \\
\hline & & E. coli 0157 & Salmonella Urbana & $\begin{array}{c}\text { S. enterica subsp. } \\
\text { arizonae }\end{array}$ \\
\hline E. coli $\mathrm{O} 157$ & Non-absorbed & $1: 3200$ & $1: 1600$ & $1: 1600$ \\
\hline Salmonella Urbana & Non-absorbed & $1: 1600$ & $1: 1600$ & $1: 800$ \\
\hline S. enterica subsp. arizonae & Non-absorbed & $1: 800$ & $1: 200$ & $1: 1600$ \\
\hline E. coli $\mathrm{O} 157$ & Salmonella Urbana & 0 & 0 & 0 \\
\hline S. enterica subsp. arizonae & Salmonella Urbana & $1: 100$ & 0 & $1: 400$ \\
\hline E. coli $\mathrm{O} 157$ & S. enterica subsp. arizonae & $1: 100$ & $1: 100$ & 0 \\
\hline Salmonella Urbana & S. enterica subsp. arizonae & $1: 200$ & $1: 800$ & 0 \\
\hline Salmonella Urbana & E. coli $\mathrm{O} 157$ & 0 & $1: 50$ & 0 \\
\hline S. enterica subsp. arizonae & E. coli $\mathrm{O} 157$ & 0 & 0 & $1: 800$ \\
\hline E. coli $\mathrm{O} 157$ & O157 + Salmonella Urbana & 0 & 0 & 0 \\
\hline Salmonella Urbana & O157 + Salmonella Urbana & 0 & 0 & $1: 50$ \\
\hline E. coli $\mathrm{O} 157$ & $\mathrm{O} 157+$ S. enterica subsp. arizonae & 0 & 0 & 0 \\
\hline S. enterica subsp. arizonae & $\mathrm{O} 157+$ S. enterica subsp. arizonae & 0 & 0 & $1: 50$ \\
\hline
\end{tabular}

*Serum was absorbed with boiled antigen for $1 \mathrm{~h}$.

their LPS carbohydrates seem to have a raised serum response against a specific LPS, in this case O157.

Different factors affect the shedding of E. coli O157: $\mathrm{H} 7$ in cattle bred in developing and developed countries. Some of

Table 7. Bactericidal activity against $E$. coli $\mathrm{O} 157: \mathrm{H} 7$ in 31 bovine serum samples with or without an ELISA response to combinations of O7, $\mathrm{O} 116$ and/or O157 E. coli LPS antigens

\begin{tabular}{|lcccc|}
\hline ELISA response & $\begin{array}{c}\text { No. of } \\
\text { serum } \\
\text { samples }\end{array}$ & $\begin{array}{c}\text { Bactericidal } \\
\text { activity } \\
\text { titre }\end{array}$ & $\begin{array}{c}\text { No. of } \\
\text { c.f.u. }\left(\times \mathbf{1 0}^{7}\right)\end{array}$ & $\begin{array}{c}\boldsymbol{P} \\
\text { value } \dagger\end{array}$ \\
\hline O157 & 1 & & & \\
O157+O7+O116 & 1 & $1: 2$ & 1.16 & 0.005 \\
O7+O116 & 1 & & & \\
O157+O7 & 1 & $1: 4$ & 5.84 & 0.001 \\
O157+O7+O116 & 3 & & & \\
O157 & 1 & & & \\
O157+O7 & 2 & $1: 8$ & 4.40 & 0.005 \\
O157+O7+O116 & 2 & & & \\
O157 & 2 & & & \\
O157+O7+O116 & 2 & $1: 16$ & 14.10 & 0.003 \\
O7 & 1 & & & \\
O7 + O116 & 1 & $1: 32$ & 15.50 & 0.002 \\
O157 & 2 & & & \\
O157+O7+O116 & 1 & $1: 64$ & 17.20 & 0.002 \\
O7 & 1 & & & \\
Total & 22 & & & \\
\hline
\end{tabular}

${ }^{*}$ Bactericidal activity was analysed by comparison with the mean c.f.u. obtained from the negative control serum sample $\left(28.83 \times 10^{8}\right.$ c.f.u. $\mathrm{ml}^{-1}$ ).

$\dagger$ One-tail analysis of variance with a significance level of $P<0.05$. these are related to climatic (Chapman et al., 1997; Hancock et al., 1997) or dietary conditions (DiezGonzalez et al., 1998), or to the age of the animals (Cray \& Moon, 1995). The frequency of isolation of E. coli O157 in dairy cattle in Mexico is low, around $1.25 \%$, according to Callaway et al. (2004), with a prevalence rate for the isolation of E. coli O157: $\mathrm{H} 7$ of around $3.0 \%$ (Navarro et al., 2006); the rate was $2.7 \%$ in a study at a slaughter plant involving beef carcasses (Varela-Hernández et al., 2007). Prevalence data reported for E. coli O157 in other Latin American countries varies. In Colombia, E. coli O157 was isolated in $6.5 \%$ of 307 rectal swabs from cattle (Mattar \& Vásquez, 1998). The prevalence of E. coli O157 in healthy young beef steers and grazing-fed cattle in Argentina was 0.5 and $6.8 \%$, respectively (Meichtri et al., 2004; Padola et al., 2004), whilst similar studies in Brazil have shown rates of $0.6 \%$ in dairy cattle (Irino et al., 2005), and $1.5 \%$ in beef and dairy calves (Cerqueira et al., 1999). In developed countries, the prevalence rates of $E$. coli O157 : H7 vary considerably from $1.8 \%$ in Japan (Miyao et al., 1998) to $23 \%$ in the USA (Smith et al., 2001). Studies conducted in England and Wales have reported prevalence rates of E. coli $\mathrm{O} 157$ ranging from 0.5 to $36 \%$ in dairy herds (Chapman et al., 1997; Hancock et al., 1997), and from 1.2 to $51 \%$ in cattle in general (Paiba et al., 2003). Although some studies involving slaughtered animals have shown that only $10 \%$ of cattle shed E. coli O157 in their faeces (Omisakin et al., 2003), a study of cattle farms in Scotland reported that $80 \%$ of E. coli transmission could arise from only $20 \%$ of the most infectious animals (Matthews et al., 2006).

The current study showed that cattle in Mexico had a serum response against E. coli $\mathrm{O} 157: \mathrm{H} 7$ in $22 \%$ of 310 
serum samples obtained from animals living under different conditions, with a prevalence of isolation of $E$. coli $\mathrm{O} 157: \mathrm{H} 7$ of $2.7 \%$. The results of this study and the review of E. coli O157:H7 isolation data from previous studies, which tend to vary widely, lead to the conclusion that variation in prevalence rates could be associated with an immune response against common epitopes present in other enteric organisms that could in turn be protecting against intestinal colonization by E. coli O157:H7. Studies are currently being undertaken to further investigate this.

\section{ACKNOWLEDGEMENTS}

Thanks to Gabriel Pérez (Facultad de Medicina, UNAM) for his technical assistance in the laboratory. This work was supported by grants from SAGARPA-CONACYT 210 and DGAPA/PAPIIT IN225705-3, UNAM.

\section{REFERENCES}

Ahmed, A., Li, J., Shiloach, Y., Robbins, J. B. \& Szu, S. C. (2006). Safety and immunogenicity of Escherichia coli O157 O-specific polysaccharide conjugate vaccine in $2-5$-year-old children. I Infect Dis 193, 515-521.

Amor, K., Heinrichs, D. E., Frirdich, E., Ziebell, K., Johnson, R. P. \& Whitfield, C. (2000). Distribution of core oligosaccharide types in lipopolysaccharides from Escherichia coli. Infect Immun 68, 11161124.

Bitzan, M., Ludwig, K., Klemt, M., Konig, H., Buren, J. \& Muller-Wiefel, D. E. (1993). The role of Escherichia coli O157 infections in the classical (enteropathic) haemolytic uraemic syndrome: results of a Central European, multicentre study. Epidemiol Infect 110, 183196.

Bundle, D. R., Gerken, M. \& Perry, M. B. (1986). Two-dimensional nuclear magnetic resonance at $500 \mathrm{MHz}$ : the structural elucidation of Salmonella serogroup N polysaccharide antigen. Can J Chem 64, 255264.

Callaway, T. R., Anderson, R. C., Tellez, G., Rosario, C., Nava, G. M., Eslava, C., Blanco, M. A., Quiroz, M. A., Olguin, A. \& other authors (2004). Prevalence of Escherichia coli O157 in cattle and swine in central Mexico. J Food Prot 67, 2274-2276.

Caprioli, A., Morabito, S., Brugère, H. \& Oswald, E. (2005). Enterohaemorrhagic Escherichia coli: emerging issues on virulence and modes of transmission. Vet Res 36, 289-311.

Caroff, M. \& Karibian, D. (2003). Structure of bacterial lipopolysaccharides. Carbohydr Res 338, 2431-2447.

Cerqueira, A. M. F., Guth, B. E. C., Joaquim, R. M. \& Andrade, J. R. C. (1999). High occurrence of Shiga toxin-producing Escherichia coli (STEC) in healthy cattle in Rio de Janeiro State, Brazil. Vet Microbiol 70, 111-121.

Chapman, P. A., Siddons, C. A., Cerdan Malo, A. T. \& Harkin, M. A. (1997). A 1-year study of Escherichia coli O157 in cattle, sheep, pigs and poultry. Epidemiol Infect 119, 245-250.

Chart, H. \& Rowe, B. (1992). Improved detection of infection by Escherichia coli $\mathrm{O} 157$ in patients with haemolytic uraemic syndrome by means of IgA antibodies to lipopolysaccharide. J Infect 24, 257-261.

Chart, H., Scotland, S. M. \& Rowe, B. (1989). Serum antibodies to Escherichia coli O157:H7 in patients with hemolytic uremic syndrome. J Clin Microbiol 27, 285-290.
Chart, H., Cheasty, T. \& Willshaw, G. A. (2002). Production of serum antibodies that recognise epitopes located on the R3 region of Escherichia coli core lipopolysaccharides by patients infected with strains of enterohaemorrhagic E. coli. J Med Microbiol 51, 10501054.

Cobbold, R. \& Desmarchelier, P. (2000). A longitudinal study of Shiga-toxigenic Escherichia coli (STEC) prevalence in three Australian diary herds. Vet Microbiol 71, 125-137.

Cravioto, A., Reyes, R. E., Trujillo, F., Uribe, F., Navarro, A., De La Roca, J. M., Hernandez, J. M., Perez, G. \& Vazquez, V. (1990). Risk of diarrhea during the first year of life associated with initial and subsequent colonization by specific enteropathogens. Am J Epidemiol 131, 886-904.

Cray, W. C., Jr \& Moon, H. W. (1995). Experimental infection of calves and adult cattle with Escherichia coli O157:H7. Appl Environ Microbiol 61, 1586-1590.

Currie, C. G. \& Poxton, I. R. (1999). The lipopolysaccharide core type of Escherichia coli O157:H7 and other non-O157 Verotoxinproducing E. coli. FEMS Immunol Med Microbiol 24, 57-62.

Currie, C. G., McCallum, K. \& Poxton, I. R. (2001). Mucosal and systemic antibody response to the lipopolysaccharide of Escherichia coli $\mathrm{O} 157$ in health and disease. J Med Microbiol 50, 345-354.

Diez-Gonzalez, F., Callaway, T. R., Kizoulis, M. G. \& Russell, J. B. (1998). Grain feeding and the dissemination of acid-resistant Escherichia coli from cattle. Science 281, 1666-1668.

Ewing, W. H. (1986). Edwards and Ewing's Identification of Enterobacteriaceae. New York: Elsevier.

Faith, N. G., Shere, J. A., Brosch, R., Arnold, K. W., Ansay, S. E., Lee, M. S., Luchansky, J. B. \& Kaspar, C. W. (1996). Prevalence and clonal nature of Escherichia coli O157: H7 on dairy farms in Wisconsin. Appl Environ Microbiol 62, 1519-1525.

Gibb, A. P., Barclay, G. R., Poxton, I. R. \& di Padova, F. (1992). Frequencies of lipopolysaccharide core types among clinical isolates of Escherichia coli defined with monoclonal antibodies. J Infect Dis 166, 1051-1057.

Gibbs, R. J., Stewart, J. \& Poxton, I. R. (2004). The distribution of, and antibody response to, the core lipopolysaccharide region of Escherichia coli isolated from the faeces of healthy humans and cattle. J Med Microbiol 53, 959-964.

Gillespie, I. A., O’Brien, S. J., Adak, G. K., Cheasty, T. \& Willshaw, G. (2005). Foodborne general outbreaks of Shiga toxin-producing Escherichia coli O157 in England and Wales 1992-2002: where are the risks? Epidemiol Infect 133, 803-808.

Greatorex, J. S. \& Thorne, G. M. (1994). Humoral immune response to Shiga-like toxin and Escherichia coli O157 lipopolysaccharide in hemolytic-uremic syndrome patients and healthy subjects. J Clin Microbiol 32, 1172-1178.

Griffin, P. M. \& Tauxe, R. V. (1991). The epidemiology of infections caused by Escherichia coli O157: H7, other enterohemorrhagic E. coli, and the associated hemolytic uremic syndrome. Epidemiol Rev 13, 60-98.

Hancock, D. D., Besser, T. E., Rice, D. H., Herriott, D. E. \& Tarr, P. I. (1997). A longitudinal study of Escherichia coli O157 in fourteen cattle herds. Epidemiol Infect 118, 193-195.

Irino, K., Kato, M. A. M. F., Vaz, T. M. I., Ramos, I. I., Souza, M. A. C., Cruz, A. S., Gomes, T. A. T., Vieira, M. A. M. \& Guth, B. E. C. (2005). Serotypes and virulence markers of Shiga toxin-producing Escherichia coli (STEC) isolated from dairy cattle in Săo Pablo State, Brazil. Vet Microbiol 105, 29-36.

Kenne, L., Lindberg, B., Unger, P., Gustafsson, B. \& Holme, T. (1982). Structural studies of the Vibrio cholerae O-antigen. Carbohydr Res 100, 341-349. 
Konadu, E., Robbins, J. B., Schiloach, J., Bryla, D. A. \& Szu, S. C. (1994). Preparation, characterization, and immunological properties in mice of Escherichia coli O157 O-specific polysaccharide-protein conjugate vaccine. Infect Immun 62, 5048-5054.

Konadu, E. Y., Parke, J. C., Jr, Tran, H. T., Bryla, D. A., Robbins, J. B. \& Szu, S. C. (1998). Investigational vaccine for Escherichia coli O157: phase 1 study of $\mathrm{O} 157$ O-specific polysaccharide-Pseudomonas aeruginosa recombinant exoprotein A conjugate in adults. J Infect Dis 177, 383-387.

Laegreid, W. W., Elder, R. O. \& Keen, J. E. (1999). Prevalence of Escherichia coli O157: H7 in range beef calves at weaning. Epidemiol Infect 123, 291-298.

Mattar, S. \& Vásquez, E. (1998). Escherichia coli O157:H7 infection in Colombia. Emerg Infect Dis 4, 126-127.

Matthews, L., Low, J. C., Gally, D. L., Pearce, M. C., Mellor, D. J., Heesterbeek, J. A. P., Chase-Topping, M., Naylor, S. W., Shaw, D. J. \& other authors (2006). Heterogeneous shedding of Escherichia coli O157 in cattle and its implications for control. Proc Natl Acad Sci U S A 103, 547-552.

Meichtri, L., Miliwebsky, E., Gioffré, A., Chinen, I., Baschkier, A., Chillemi, G., Guth, B. E. C., Masana, M. O., Cataldi, A. \& other authors (2004). Shiga toxin-producing Escherichia coli in healthy young beef steers from Argentina: prevalence and virulence properties. Int J Food Microbiol 96, 189-198.

Miyao, Y., Kataoka, T., Nomoto, T., Kai, A., Itoh, T. \& Itoh, K. (1998). Prevalence of verotoxin-producing Escherichia coli harbored in the intestine of cattle in Japan. Vet Microbiol 61, 137-143.

Navarro, A., Eslava, C., Hernandez, U., Navarro-Henze, J. L., Avilés, M., Garcia de la Torre, G. \& Cravioto, A. (2003). Antibody response to Escherichia coli $\mathrm{O} 157$ and other lipopolysaccharides in healthy children and adults. Clin Diagn Lab Immunol 10, 797-801.

Navarro, A., Eslava, C., Gutierrez, A., Licona, D., León, L., Pérez, G., Díaz, M., Díaz, S. P., Uribe, M. \& other authors (2006). Immune response to Escherichia coli O157 LPS in dairy cattle in Mexico is not associated with intestinal colonization by Escherichia coli O157 strains. In Abstracts of the 6th International Symposium on Shiga Toxin (Verocytotoxin)-producing Escherichia coli infections (VTEC 2006 Melbourne), Melbourne, Australia,. abstract P06.01.04.

Naylor, S. W., Gally, D. L. \& Low, J. C. (2005). Enterohaemorrhagic E. coli in veterinary medicine. Int J Med Microbiol 295, 419-441.

Nishiuchi, Y., Doe, M., Hotta, H. \& Kobayashi, K. (2000). Structure and serologic properties of $\mathrm{O}$-specific polysaccharide from Citrobacter freundii possessing cross-reactivity with Escherichia coli O157:H7. FEMS Immunol Med Microbiol 28, 163-171.

Omisakin, F., MacRae, M., Ogden, I. D. \& Strachan, N. J. C. (2003). Concentration and prevalence of Escherichia coli $\mathrm{O} 157$ in cattle feces at slaughter. Appl Environ Microbiol 69, 2444-2447.
Ørskov, F. \& Ørskov, I. (1984). Serotyping of Escherichia coli. Meth Microbiol 14, 43-112.

Padola, N. L., Sanz, M. E., Blanco, J. E., Blanco, M., Blanco, J., Etcheverria, A. I., Arroyo, G. H., Usera, M. A. \& Parma, A. E. (2004). Serotypes and virulence of bovine Shigatoxigenic Escherichia coli (STEC) isolated from a feedlot in Argentina. Vet Microbiol 100, 3-9.

Paiba, G. A., Wilesmith, J. W., Evans, S. J., Pascoe, S. J. S., Smith, R. P., Kidd, S. A., Ryan, J. B. M., McLaren, I. M., Chappell, S. A. \& other authors (2003). Prevalence of faecal excretion of Verocytotoxigenic Escherichia coli $\mathrm{O} 157$ in cattle in England and Wales. Vet Rec 153, 347-353.

Perry, M. B. \& Bundle, D. R. (1990). Antigenic relationships of the lipopolysaccharides of Escherichia hermannii strains with those of Escherichia coli $\mathrm{O} 157: \mathrm{H7}$, Brucella melitensis, and Brucella abortus. Infect Immun 58, 1391-1395.

Perry, M. B., MacLean, L. \& Griffith, D. W. (1986). Structure of Ochain polysaccharide of the phenol-phase soluble lipopolysaccharide of Escherichia coli O157: H7. Biochem Cell Biol 64, 21-28.

Qadri, F., Mohi, G., Hossain, J., Azim, T., Khan, A. M., Salam, M. A., Sack, R. B., Albert, M. J. \& Svennerholm, A.-M. (1995). Comparison of the vibriocidal antibody response in cholera due to Vibrio cholerae O139 Bengal with the response in cholera due to Vibrio cholerae O1. Clin Diagn Lab Immunol 2, 685-688.

Rangel, J. M., Sparling, P. H., Crowe, C., Griffin, P. M. \& Swerdlow, D. L. (2005). Epidemiology of Escherichia coli O157:H7 outbreaks, United States, 1982-2002. Emerg Infect Dis 11, 603-609.

Rice, E. W., Sowers, E. G., Johnson, C. H., Dunnigan, M. E., Strockbine, N. A. \& Edberg, S. C. (1992). Serological cross-reactions between Escherichia coli $\mathrm{O} 157$ and other species of the genus Escherichia. J Clin Microbiol 30, 1315-1316.

Samuel, G., Hogbin, J.-P., Wang, L. \& Reeves, P. R. (2004). Relationships of the Escherichia coli O157, O111, and O55 O-antigen gene cluster with those of Salmonella enterica and Citrobacter freundii, which express identical O antigens. J Bacteriol 186, 6536-6543.

Smith, D., Blackford, M., Younts, S., Moxley, R., Gray, J., Hungerford, L., Milton, T. \& Klopfenstein, T. (2001). Ecological relationship between the prevalence of cattle shedding Escherichia coli O157:H7 and characteristics of the cattle or conditions of the feedlot pen. $J$ Food Prot 64, 1899-1903.

Varela-Hernández, J. J., Cabrera-Diaz, E., Cardona-López, M. A., Ibarra-Velázquez, L. M., Rangel-Villalobos, H., Castillo, A., Torres-Vitela, M. R. \& Ramírez-Alvarez, A. (2007). Isolation and characterization of Shiga toxin-producing Escherichia coli O157:H7 and non-O157 from beef carcasses at a slaughter plant in Mexico. Int $J$ Food Microbiol 113, 237-241.

Westphal, O. \& Jann, K. (1965). Bacterial lipopolysaccharide: extraction with phenol-water and further applications of the procedure. Meth Carbohydr Chem 5, 83-91. 